\title{
Evaluation of Fungicides for the Control of Peronospora belbahrii on Sweet Basil in New Jersey
}

Kathryn Homa, Department of Plant Biology and Pathology, Rutgers University, New Brunswick, NJ 08901 and IR-4 Project Headquarters, Rutgers University, Princeton, NJ 08540; William P. Barney, IR-4 Project Headquarters, Rutgers University; Daniel L. Ward and Christian A. Wyenandt, Rutgers Agricultural Research and Extension Center, Bridgeton 08302; and James E. Simon, The New Use Agriculture and Natural Plant Products Program, Department of Plant Biology and Pathology, Rutgers University

\begin{abstract}
Homa, K., Barney, W. P., Ward, D. L., Wyenandt, C. A., and Simon, J. E. 2014. Evaluation of fungicides for the control of Peronospora belbahrii on sweet basil in New Jersey. Plant Dis. 98:1561-1566.

Basil downy mildew (BDM), caused by the fungus-like oomycete pathogen Peronospora belbahrii, has become a destructive disease of sweet basil (Ocimum basilicum). Without proper management, BDM can cause complete crop loss. Currently, there are no commercially available sweet basil cultivars with genetic resistance to BDM. Because BDM is a relatively new disease of basil in the United States, there are few currently registered conventional or organic fungicides labeled for its control. Fungicide efficacy trials were conducted in 2010 and 2011 at Rutgers Agricultural Research and Extension Center in Bridgeton, NJ. During both years, seven biological fungicide treatments were field evaluated, including hydrogen dioxide; extract of

Reynoutria sachalinensis; Bacillus pumilus strain QST 2808; a mixture of rosemary oil, clove oil, and thyme oil; mono- and dipotassium salts of phosphorous acid; sesame oil; copper hydroxide; and a combination of sesame oil + cupric hydroxide. Six conventional fungicides evaluated included mandipropamid, fluopicolide, propamocarb hydrochloride, cyazofamid, azoxystrobin, and fenamidone. In both years, monoand dipotassium salts of phosphorous acid provided the best control. Moderate disease suppression was provided by mandipropamid, cyazofamid, and fluopicolide compared with the control in 2010 and mandipropamid, cyazofamid, and copper hydroxide compared with the control in 2011.
\end{abstract}

Sweet basil (Ocimum basilicum L.) is the most economically important culinary herb in the United States $(8,35,59)$. In recent years, downy mildew caused by Peronospora belbahrii Thines has become one of the most destructive diseases in sweet basil production in the United States and around the world $(5,18)$. The disease was first reported in Uganda in 1932 as Peronospora spp. and again in 1937 as $P$. lamii as causing defoliation and death of sweet basil $(13,14)$. The disease was not reported again until 2001 in Switzerland $(15,17)$. Following this confirmation, other countries throughout the world reported the first occurrences of basil downy mildew (BDM): Italy in 2003, France and Belgium in 2004, South Africa in 2005, Iran in 2006, Cameroon in 2007, Argentina in 2008, Taiwan in 2009, and Hungary in 2010 $(6,7,9,10,16,23,32,54,60)$.

BDM was first discovered and reported in the United States in southern Florida in fall 2007 (53). Shortly afterward, BDM was observed throughout the northeastern United States in summer $2008(18,22,61)$ and it has been spreading ever since into many northern, southeastern, central, and Pacific states, including Hawaii $(28,31)$. In 2011, the pathogen was reported in Canada (55). The pathogen that was first reported in the United States in 2007 was genetically identical to the pathogen discovered in Switzerland in 2001 (53). Unfortunately, the epidemiology of P. belbahrii is still unknown. It is believed that the pathogen has spread globally in recent years via the shipment of infested seed as well as through wind currents $(18,58)$.

Grown in both the field and the greenhouse in many regions of the United States, basil is an important source of income for many vegetable and herb growers $(53,56,57,59)$. In 2010 , approximately 11,000 acres of basil were grown in the United States (C. A. Wyen-

Corresponding author: C. A. Wyenandt, E-mail: wyenandt@ rutgers.edu

Accepted for publication 8 May 2014.

http://dx.doi.org/10.1094/PDIS-02-14-0200-RE

(C) 2014 The American Phytopathological Society andt, personal communication). Since 2007, the disease has reached epidemic proportions in the United States and has remained a major threat to basil production (22). Without proper management, BDM can cause $100 \%$ crop loss $(12,48,62)$. Unfortunately, because BDM has now become established in regions of the United States (e.g., such as southern Florida) and other countries where temperatures and structures allow for year-round production, the pathogen will continue to remain a significant threat to the worldwide sweet basil industry. Currently, there are no commercially available sweet basil cultivars resistant to BDM. Without genetic resistance to BDM, all sweet basil produced in the United States is vulnerable and will require the use of fungicide applications for its control $(48,62)$. Since its introduction, many commercial basil growers in the United States rely on a few registered fungicides for its control (62). Currently, the only federally registered conventional fungicide products are cyazofamid (Ranman, FMC Agricultural Products) and mandipropamid (Revus, Syngenta Crop Protection). Other conventional fungicide products including azoxystrobin (Heritage, Syngenta Professional Products; 24c registration for transplants), mefenoxam (Subdue Max, Syngenta Professional Products; 24c registration for transplants), and mandipropamid (Micora, Syngenta Crop Protection; 24c registration for transplants) have temporary or state registrations. Conventional fungicide products in the IR-4 registration process include fenamidone (Reason 500 SC, Bayer CropScience), fluopicolide (Presidio, Valent U.S.A. Corporation Agricultural Products), and oxathiapiprolin (Syngenta Crop Protection). Organic Materials Review Institute (OMRI Listed) federally registered fungicide products include Streptomyces lydicus (Actinovate AG, Novozymes BioAg Inc.), Bacillus amyloliquefaciens strain D747 (Double Nickel 55 and LC, Certis U.S.A.), extract of Reynoutria sachalinensis (Regalia, Marrone Bio Innovations), neem oil (Trilogy, Certis U.S.A.), potassium bicarbonate (Eco-Mate Armicarb O, Helena Chemical Company; Milstop, BioWorks Inc.), and hydrogen dioxide (Oxidate, BioSafe Systems LLC). Biological fungicide products that are not OMRI Listed include mono- and di-potassium salts of phosphorous acid (K-Phite, Plant Food Systems), phosphorous acid, mono- and 
dipotassium salts (Confine Extra, Winfield Solutions LLC), potassium bicarbonate (Armicarb 100, Helena Chemical Company), potassium phosphite (Fosphite, JH Biotech, Inc.; FungiPhite, Plant Protectants, LLC; Prophyt, Helena Chemical Company; Rampart, Loveland Products, Inc.), a combination of potassium phosphate and potassium phosphite (Phorcephite, Loveland Products, Inc.), sodium tetraborohydrate decahydrate (Prev-Am Ultra ORO Agri, Inc.), and hydrogen peroxide, peroxyacetic acid (Rendition, Certis USA LLC). Many of these conventional and organic products have been evaluated only in small efficacy studies in basil production areas of the United States, with varying results (1-4,19-21,24-27,29,30,33,36-47,49-52).

The objective of this study was to evaluate a selected number of conventional and biological fungicides over a 2-year period under New Jersey field conditions and identify the most promising for the control of BDM. Conventional fungicides that prove to be efficacious for controlling BDM may receive federal registration.

\section{Materials and Methods}

Field experiments and fungicide treatments. Fungicide efficacy trials for the control of BDM were conducted during 2010 and 2011 at Rutgers Agricultural Research and Extension Center (RAREC) in Bridgeton, NJ. During both years, in total, six conventional fungicides, including mandipropamid, fluopicolide, propamocarb hydrochloride (Previcur Flex; Bayer CropScience), cyazofamid, azoxystrobin (Amistar; Syngenta Crop Protection), and fenamidone, were evaluated. In total, seven biological fungicides, including hydrogen dioxide; extract of $R$. sachalinensis; $B$. pumilus strain QST 2808 (Sonata; AgraQuest Inc.); a mixture of rosemary oil, clove oil, and thyme oil (Sporatec AG; Brandt Consolidated, Inc.); mono- and dipotassium salts of phosphorous acid, sesame oil (Organocide; Organic Laboratories, Inc.); copper hydroxide (Nu-Cop, Albaugh Inc.); and a combination of sesame oil + cupric hydroxide (Organocide + NuCop), were used. Regalia, Sonata, Oxidate, Sporatec, Organocide, and NuCop are listed by the OMRI (http://www.omri.org/about) as allowed for use in organic production. All biological and conventional fungicides were applied at labeled rates in both years of the study. Information regarding the fungicide, rates, active ingredients, and FRAC groups is listed in Tables 1 and 2.

In total, 55 and 70 flats were hand seeded with 'Italian Large Leaf' sweet basil from Johnny's Selected Seeds in 128-cell flats containing Redi-Earth Coir Mix Sun Gro Redi-Earth Plug and Seedling Mix Series Growing Medium (Sun Grow Horticulture) on
10 May 2010 and 18 May 2011, respectively. Plants were maintained for 4 to 5 weeks in the Rutgers School of Environmental and Biological Sciences (SEBS) greenhouse complex in 2010 and by a commercial grower in 2011. Maintenance fertilizers and insecticides were applied as needed.

Flats were transported to the field site at RAREC on 15 June 2010 and 16 June 2011. At RAREC during both years, plants were allowed to acclimate outdoors for approximately 1 week before being hand transplanted into the field into raised beds covered with 1.25-ml black plastic mulch on 21 June 2010 and 22 June 2011. Each year, drip irrigation was laid down the center on each bed when the black plastic mulch was laid. All beds were spaced approximately $1.5 \mathrm{~m}$ apart with guard rows between each treatment row in both years. The trial was a randomized complete block design with four replicates. Each experimental unit was $3 \mathrm{~m}$ long, containing two rows of transplanted basil centered $41 \mathrm{~cm}$ apart Plants were spaced approximately $23 \mathrm{~cm}$ between each plant in 2010 and approximately $30.5 \mathrm{~cm}$ apart in 2011. During both years, each experimental unit contained approximately 10 plants per row for a total of approximately 20 plants. There were $1.5-\mathrm{m}$ buffers between each plot. All guard rows consisting of Italian Large Leaf basil were transplanted between each treatment row during the last week of June during both years. A plant count and replant of basil plants was conducted on 29 June 2011.

During the course of the study, the field was fertilized via drip irrigation on 7, 22, and 29 July; 5 and 30 August; and 3 and 15 September 2010 and on 7 and 26 July; 2, 22, and 31 August; and 13 September 2011 using 1.9 kg of 20N-20P-20K (Peters Professional 20-20-20; Scotts-Sierra Horticultural Products Company). Additionally, the trial was drip irrigated on 21, 22, and 24 June; 6 and 24 July; 3, 6, 13, and 24 August; and 10 and 12 September 2010 and approximately two to three times per week in 2011 . The run time for each irrigation event varied from 2 to $9 \mathrm{~h}$ in 2010 and 1 to $8 \mathrm{~h}$ in 2011. In 2010, the trial was also irrigated using overhead irrigation on three separate dates (6, 10, and 13 August 2010) to help create an environment that was favorable for disease development. In 2011, the trial was not irrigated using overhead irrigation because conditions were favorable for disease pressure during the course of the trial. Two nonlabeled insecticide maintenance sprays were made on 9 and 14 September 2010; esfenvalerate (Asana; DuPont Crop Protection) and thiamethoxam (Platinum; Syngenta Crop Protection) were applied at rates according to local standard practices to keep Lepidopteran and Coleopteran populations in check. On 15 July 2011, an herbicide maintenance spray

Table 1. Fungicide, rate, active ingredient, FRAC group, and ratings by date and area under the disease progress curve (AUDPC) values for basil downy mildew development in 2010

\begin{tabular}{|c|c|c|c|c|c|c|c|c|c|c|c|c|c|}
\hline \multirow[b]{2}{*}{ Fungicide } & \multirow[b]{2}{*}{ Rate ha $\mathbf{~}^{-1}$} & \multirow[b]{2}{*}{ Active ingredient } & \multirow[b]{2}{*}{ FRAC $^{\mathbf{y}}$} & \multicolumn{10}{|c|}{ Rating date (percent basil downy mildew) ${ }^{x}$} \\
\hline & & & & $8 / 7$ & $8 / 15$ & $8 / 21$ & $8 / 28$ & $9 / 4$ & 9/11 & 9/18 & $9 / 25$ & $10 / 2$ & $\mathbf{A U D P C}^{\mathbf{z}}$ \\
\hline Regalia & $\begin{array}{l}0.5 \%(\mathrm{vol} / \mathrm{vol}) / \\
189 \text { liters }\end{array}$ & Reynoutria sachalinensis & NA & 0 & 0 & 51 & 88 & 92 & 85 & 56 & 85 & 90 & $2,862 \mathrm{a}$ \\
\hline Untreated control & $\ldots$ & $\ldots$ & $\ldots$ & 0 & 0 & 57 & 93 & 94 & 65 & 36 & 91 & 94 & $2,835 \mathrm{a}$ \\
\hline Sonata & 9.35 liters & Bacillus pumilus & NA & 0 & 0 & 20 & 95 & 90 & 84 & 45 & 91 & 90 & $2,775 \mathrm{ab}$ \\
\hline Organocide & 0.146 liter & Sesame oil & NA & 1 & 0 & 32 & 87 & 92 & 77 & 47 & 87 & 91 & $2,726 \mathrm{ab}$ \\
\hline Oxidate & 1 liter/100 liters & Hydrogen dioxide & NA & 4 & 2 & 76 & 71 & 76 & 75 & 34 & 82 & 83 & $2,659 \mathrm{ab}$ \\
\hline \multirow[t]{2}{*}{ Sporatec AG } & 2.3 liters + & & & & & & & & & & & & \\
\hline & SafTcide & Rosemary, clove, and thyme oils & NA & 0 & 0 & 37 & 85 & 89 & 61 & 34 & 90 & 86 & $2,577 \mathrm{bcd}$ \\
\hline Previcur Flex & 1.4 liters & Propamocarb $\mathrm{HCl}$ & 28 & 0 & 0 & 23 & 77 & 86 & 77 & 44 & 76 & 79 & $2,464 \mathrm{~cd}$ \\
\hline Amistar & 1.13 liters & Azoxystrobin & 11 & 1 & 0 & 18 & 74 & 80 & 75 & 53 & 74 & 84 & $2,429 \mathrm{~d}$ \\
\hline Reason & 0.4 liter & Fenamidone & 11 & 0 & 0 & 6 & 44 & 75 & 85 & 76 & 80 & 82 & 2,369 de \\
\hline NuCop & $1.12 \mathrm{~kg}$ & Copper hydroxide & M1 & 0 & 0 & 22 & 69 & 82 & 75 & 38 & 82 & 76 & $2,361 \mathrm{de}$ \\
\hline Organocide + NuCop & $73 \mathrm{ml}+1.12 \mathrm{~kg}$ & Sesame oil + copper hydroxide & NA, M1 & 0 & 0 & 10 & 70 & 80 & 64 & 40 & 74 & 55 & $2,171 \mathrm{ef}$ \\
\hline Ranman & 0.2 liter & Cyazofamid & 21 & 0 & 0 & 19 & 35 & 56 & 75 & 70 & 72 & 73 & $2,141 \mathrm{f}$ \\
\hline Revus & 0.58 liter & Mandipropamid & 40 & 0 & 0 & 3 & 25 & 62 & 77 & 76 & 81 & 67 & $2,139 \mathrm{f}$ \\
\hline Presidio & 0.29 liter & Fluopicolide & 43 & 0 & 0 & 2 & 14 & 42 & 64 & 55 & 76 & 67 & $1,799 \mathrm{~g}$ \\
\hline K-Phite & 7 liters & Phosphorous acid & 33 & 0 & 0 & 1 & 3 & 12 & 4 & 3 & 5 & 2 & $439 \mathrm{~h}$ \\
\hline
\end{tabular}

${ }^{\mathrm{x}}$ Downy mildew incidence was recorded by examining 25 randomly selected leaf samples per experimental unit on nine dates during the growing season to determine the mean percentage of leaves with symptoms of downy mildew.

y FRAC grouping; NA = not applicable.

${ }^{\mathrm{z}}$ Means followed by the same letter are not significantly different according to least significant difference test at $P<0.0001$. 
using gramoxone (Gramoxone SL; Syngenta Crop Protection) was done to eliminate weeds between the black plastic mulch rows and at the ends of the plot. During both years, to prevent basil plants from going to seed, plants were manually trimmed back by hand using hedge clippers to approximately $50 \%$ of their height to a 15 to $30-\mathrm{cm}$ height on 17 and 30 July 2010 and 20 July and 6 August 2011. On 5 August 2010 and 4 August 2011, basil plants infected with $P$. belbahrii were introduced at the end of each row to promote disease development. Infected plants were obtained from a local basil grower's field in Cumberland County, NJ in 2010 and from a retail store in Cumberland County, NJ in 2011.

In total, nine fungicide applications $(2,11,19$, and 27 August and 3, 9, 15, 23, and 29 September) were applied in 2010 and eight applications (1, 8, 17, 23, and 30 August and 5, 12, and 20 September) were applied in 2011. All fungicide applications in both years were made with a tractor-mounted pressurized sprayer with three hollow-cone D4-25, disc core crop nozzles (Tee-Jet), with one nozzle over the top and one nozzle on each side directed inward at a $45^{\circ}$ angle. All applications were applied at approximately 58 psi at the tank and approximately 48 psi at the boom.

To evaluate the efficacy of the biological and conventional fungicide treatments during both years, all experimental units in the trial were rated weekly (every 7 days) for the incidence and severity of BDM. Incidence ratings were recorded by examining 25 randomly selected leaf samples per experimental unit to determine the mean percentage of leaves with active sporulation. BDM severity ratings were determined by using an ordered categorical scale of 0 to 3 where $0=$ no sporulation, $1=$ light sporulation, $2=$ moderate sporulation, and 3 = heavy sporulation on the abaxial surface of the leaves (M. T. McGrath, personal communication). Weekly BDM incidence ratings began on 7 August 2010 and 30 July 2011 and took place on a total of nine dates $(7,15,21$, and 28 August; 4, 11, 18 , and 25 September; and 2 October) in 2010 and a total of 10 dates (30 July; 6, 13, 20, and 26 August; 3, 10, 17, and 24 September; and 1 October) in 2011. BDM severity ratings were conducted on a total of six dates (28 August; 4, 11, 18, and 25 September; and 2 October) in 2010 and seven dates (20 and 26 August; 3, 10, 17, and 24 September; and 1 October) in 2011.

Statistical analysis. All data from 2010 and 2011 were analyzed separately because downy mildew ratings were recorded on different dates each year. The GLM procedure of the SAS System (version 9.3; SAS Institute) was used for analysis of variance. The area under the disease progress curve (AUDPC) summarized the pro- gress of disease severity. For this study, AUDPC values were calculated for each treatment for both years. Means of the AUDPC values were separated according to the least significant difference test at $P<0.0001$.

\section{Results}

In 2010, the first report of BDM in the mid-Atlantic region was confirmed near Vineland, NJ on 9 July (C. A. Wyenandt, personal communication). Fungicide applications were initiated on 2 August 2010 and the first rating was conducted on 7 August. During the first rating date, BDM was observed in the sesame oil-, hydrogen dioxide-, and azoxystrobin-treated experimental units indicating active disease pressure in the trial area. However, BDM was not found in the untreated (control) experimental units until the third rating on 21 August 2010. Disease pressure in the trial began to increase on 21 August, with an untreated control average rating of 57\% incidence (Table 1). From 28 August to 2 October, disease severity increased with disease development in the untreated control, ranging from 91 to $94 \%$ by the end of the trial. (Table 1; Fig. 1). The reduction in overall disease pressure in mid-September was most likely due to a change in environmental conditions, including low temperatures at the time.

Mono- and dipotassium salts of phosphorous acid applied weekly at a rate of 7 liters/ha provided the most efficacious control of BDM in 2010 (Table 1; Fig. 1), where the highest weekly average of BDM was $12 \%$ (Table 1). The AUDPC value for mono- and dipotassium salts of phosphorous acid was significantly lower compared with all other conventional and biological fungicide treatments in 2010 (Table 1). Based on AUDPC values, moderate disease suppression was provided by mandipropamid, cyazofamid, and fluopicolide compared with the untreated control and most biological and conventional fungicides (Table 1; Fig. 1). However, by the end of the trial, suppression was lost by all treatments except mono- and dipotassium salts of phosphorous acid (Fig. 1). With the exception of mono- and dipotassium salts of phosphorous acid, none of the biological fungicides provided an adequate level of control of BDM in 2010 and were comparable with the untreated control (Table 1; Fig. 1).

Ratings ended in early October 2010, when most plants were severely infected with BDM. Total rainfall accumulations at RAREC for the months of June, July, August, September, and October were 5.97, 10.49, 7.52, 11.07, and $14.10 \mathrm{~cm}$, respectively. Minimum mean temperatures at RAREC for the months of June, July, Au-

Table 2. Fungicide, rate, active ingredient, FRAC group, and ratings by date and area under the disease progress curve (AUDPC) values for basil downy mildew development in 2011

\begin{tabular}{|c|c|c|c|c|c|c|c|c|c|c|c|c|c|c|}
\hline \multirow[b]{2}{*}{ Treatment } & \multirow[b]{2}{*}{ Rate ha $^{-1}$} & \multirow[b]{2}{*}{ Active ingredient } & \multirow[b]{2}{*}{ FRAC $^{\mathbf{y}}$} & \multicolumn{11}{|c|}{ Rating date (percent basil downy mildew) } \\
\hline & & & & $7 / 30$ & $8 / 6$ & $8 / 13$ & $8 / 20$ & $8 / 26$ & $9 / 3$ & $9 / 10$ & $9 / 17$ & $9 / 24$ & $10 / 1$ & $\mathbf{A U D P C}^{\mathbf{z}}$ \\
\hline Amistar & 1.13 liters & Azoxystrobin & 11 & 0 & 0 & 0 & 5 & 37 & 60 & 88 & 70 & 61 & 43 & $2,263 \mathrm{a}$ \\
\hline Untreated control & $\ldots$ & $\ldots$ & $\ldots$ & 0 & 0 & 0 & 15 & 55 & 85 & 78 & 76 & 80 & 74 & $2,246 \mathrm{a}$ \\
\hline Reason & 0.4 liter & Fenamidone & 11 & 0 & 0 & 0 & 1 & 2 & 34 & 83 & 84 & 80 & 50 & $2,234 \mathrm{a}$ \\
\hline Previcur Flex & 1.4 liters & Propamocarb $\mathrm{HCl}$ & 28 & 0 & 1 & 1 & 8 & 35 & 62 & 68 & 60 & 60 & 60 & $2,136 \mathrm{ab}$ \\
\hline Regalia & $0.5 \%(\mathrm{vol} / \mathrm{vol}) /$ & & & & & & & & & & & & & \\
\hline Oroanocide + NuCon & $\begin{array}{l}189 \text { liters } \\
73 \mathrm{ml}+1.12 \mathrm{~kg}\end{array}$ & $\begin{array}{l}\text { Reynoutria sachalinensis } \\
\text { Sesame oil }+\end{array}$ & NA & 0 & 0 & 0 & 5 & 28 & 62 & 76 & 71 & 72 & 65 & $2,113 a b$ \\
\hline Organocide + ivucop & $15 \mathrm{mIl}+1.12 \mathrm{~kg}$ & copper hydroxide & NA, M1 & 0 & 0 & 1 & 3 & 37 & 57 & 73 & 62 & 69 & 69 & $2,110 \mathrm{ab}$ \\
\hline Presidio & 0.29 liter & Fluopicolide & 43 & 0 & 0 & 0 & 0 & 17 & 47 & 83 & 76 & 76 & 33 & $2,089 \mathrm{ab}$ \\
\hline Sonata & 9.35 liters & Bacillus pumilus & NA & 0 & 0 & 0 & 6 & 37 & 71 & 86 & 81 & 83 & 79 & $2,027 \mathrm{ab}$ \\
\hline Organocide & 0.146 liter & Sesame oil & NA & 0 & 0 & 0 & 18 & 39 & 77 & 84 & 69 & 69 & 64 & 1,939 a-c \\
\hline Oxidate & 1 liter/100 liters & Hydrogen dioxide & NA & 0 & 0 & 0 & 29 & 67 & 71 & 77 & 62 & 68 & 81 & $1,921 \mathrm{a}-\mathrm{c}$ \\
\hline Sporatec AG & $\begin{array}{c}2.3 \text { liters }+ \\
\text { SafTcide }\end{array}$ & $\begin{array}{l}\text { Rosemary, clove, and } \\
\text { thyme oils }\end{array}$ & NA & 0 & 0 & 0 & 9 & 43 & 69 & 85 & 68 & 65 & 67 & $1,898 \mathrm{a}-\mathrm{c}$ \\
\hline NuCop & $1.12 \mathrm{~kg}$ & Copper hydroxide & M1 & 0 & 0 & 0 & 4 & 24 & 55 & 74 & 64 & 61 & 62 & $1,690 \mathrm{bc}$ \\
\hline Revus & 0.58 liter & Mandipropamid & 40 & 0 & 0 & 0 & 0 & 8 & 16 & 55 & 61 & 67 & 32 & $1,653 \mathrm{bc}$ \\
\hline Ranman & 0.2 liter & Cyazofamid & 21 & 0 & 0 & 0 & 0 & 6 & 19 & 62 & 74 & 59 & 21 & $1,533 \mathrm{c}$ \\
\hline K-Phite & 7 liters & Phosphorous acid & 33 & 0 & 0 & 0 & 0 & 2 & 3 & 3 & 0 & 2 & 24 & $896 \mathrm{~d}$ \\
\hline
\end{tabular}

${ }^{\mathrm{x}}$ Downy mildew incidence was recorded by examining 25 randomly selected leaf samples per experimental unit on nine dates during the growing season to determine the mean percentage of leaves with symptoms of downy mildew.

y FRAC grouping; NA = not applicable.

${ }^{\mathrm{z}}$ Means followed by the same letter are not significantly different according to least significant difference test at $P<0.0001$. 
gust, September, and October were $19,20,19,16$, and $9^{\circ} \mathrm{C}$, respectively. Maximum mean temperatures at RAREC for the months of June, July, August, September, and October were 30, 31, 29, 27, and $19^{\circ} \mathrm{C}$, respectively.

In 2011, the first report of BDM in the mid-Atlantic region was confirmed near Vineland, NJ on 20 July (C. A. Wyenandt, personal communication). No BDM was observed during the first rating date (30 July). Fungicide applications were initiated on 1 August 2011. The presence of BDM was observed on 6 August 2011 in one of the propamocarb- $\mathrm{HCl}$ plots, indicating active disease pressure. BDM was found in the untreated experimental units during the fourth rating on 20 August 2011. Disease severity increased on 20 August, with an average rating of $15 \%$ in the untreated control (Table 2). Disease increased substantially from 26 August to 24 September, with the untreated control experimental units ranging from 55 to $85 \%$ severity infection (Fig. 2).

As in 2010, mono- and dipotassium salts of phosphorous acid (FRAC Code 33) provided the most efficacious, season-long control of BDM in 2011 (Table 2). When mono- and dipotassium salt of phosphorous acid was applied on a weekly basis during the study, the highest average percent of BDM was $24 \%$ (Table 2). The AUDPC value for mono- and dipotassium salts of phosphorous acid was significantly lower compared with all other conventional and biological fungicide treatments in 2011 (Table 2). Based on AUDPC values, moderate disease suppression was provided by mandipropamid, cyazofamid, and copper hydroxide compared with the untreated control and most biological and conventional fungi- cides (Table 2). However, by the end of the trial, suppression was lost by all treatments except mono- and dipotassium salts of phosphorous acid (Fig. 2). None of the biological fungicides provided an adequate level of control of BDM in 2011 and were comparable with the untreated control (Table 2). Ratings ended in early October 2011, when most plants were severely infected with BDM. Total rainfall accumulations at RAREC for the months of June, July, August, September, and October were 8.97, 14.81, 57.45, 12.70 , and $9.96 \mathrm{~cm}$, respectively. Minimum mean temperatures at RAREC for the months of June, July, August, September, and October were $17,21,18,17$, and $8^{\circ} \mathrm{C}$, respectively. Maximum mean temperatures at RAREC for the months of June, July, August, September, and October were $29,32,28,26$, and $19^{\circ} \mathrm{C}$, respectively.

\section{Discussion}

BDM fungicide efficacy trials have been conducted throughout the United States including Florida (24-30,33,34,36-52), New York (19-21), Illinois $(3,4)$, and Connecticut $(1,2)$. In these trials, many of the same fungicides were tested, with variable results obtained at each trial site (1-4,19-21,29,30,33,36,37,41,42, $44,47,49-52)$. In both years of this study in New Jersey, mono- and dipotassium salts of phosphorous acid provided the most efficacious control of BDM (Figs. 1 and 2). However, when monoand dipotassium salts of phosphorous acid were tested in other fungicide efficacy trials in Florida and New York, mono- and dipotassium salts of phosphorous acid provided controls that were

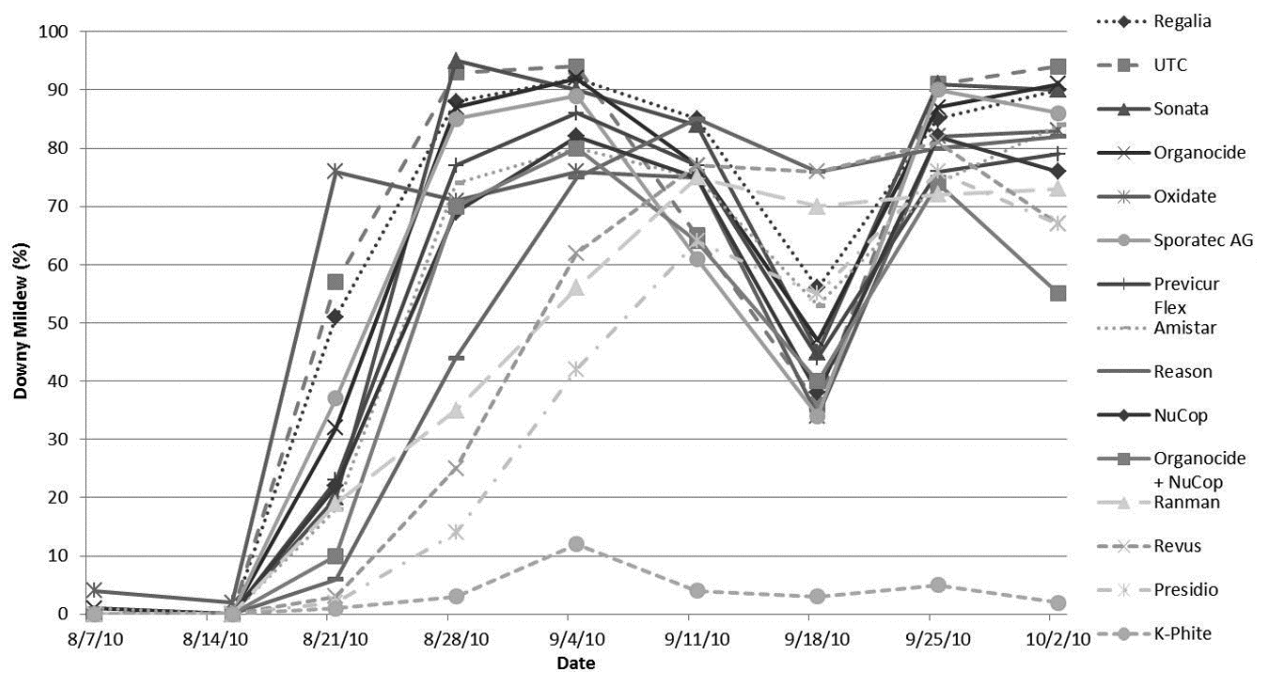

Fig. 1. Percent incidence of basil downy mildew by week for selected fungicides in 2010 at the Rutgers Agricultural Research and Extension Center in Bridgeton, NJ.
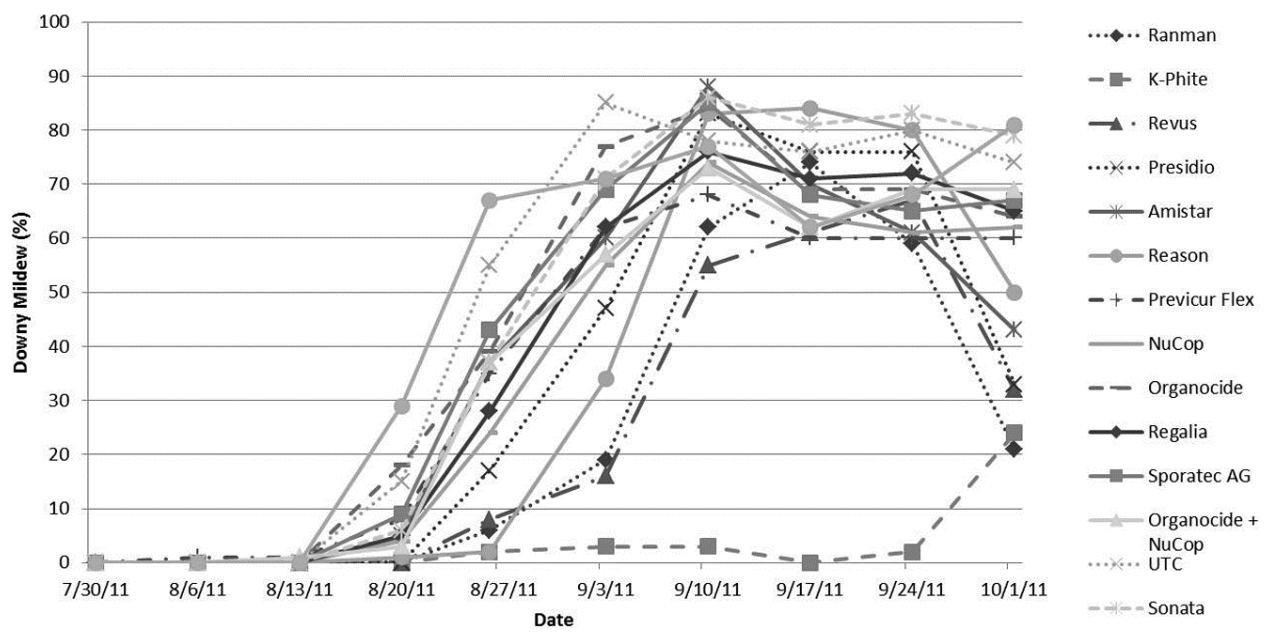

Fig. 2. Percent incidence of basil downy mildew by week for selected fungicides in 2011 at the Rutgers Agricultural Research and Extension Center in Bridgeton, NJ. 
not as high as other fungicides tested $(21,36)$. A comparison of these trials cannot be made because there are a number of factors that make it difficult to directly compare the results obtained in New Jersey with studies in other states. Some of these factors include differences in application rates $(37,41,44,47)$, plant maturity $(34,38,40,41,47,50)$, number of applications $(39,42,44)$, use of adjuvants (1-4,19-21,36-47,49-52), varying levels of disease pressure $(3,19,20)$, and different rating scales used at different locations $(1,2,36-47,49-52)$.

Downy mildews such as $P$. belbahrii and others (Pseudoperonospora spp., Plasmopara spp., Sclerospora spp., and Bremia spp.) are some of the most economically important diseases of vegetables and leafy green crops in the world and, without proper management, significant losses can occur (12). To help maintain control of BDM and reduce the chances for fungicide resistance development, it is important for conventional basil growers to (i) initiate a regular fungicide maintenance program with a labeled fungicide prior to the arrival of the pathogen, (ii) limit the number of applications of high-risk fungicides applied during the production season, (iii) rotate fungicides with different modes-of-action, and (iv) apply tank mixtures of high-risk and protectant fungicides (11). Current fungicide recommendations for the control of BDM in New Jersey and the mid-Atlantic region include applying a phosphorous acid fungicide (FRAC code 33) at a high rate on a weekly basis prior to the onset of disease. Phosphorous acid fungicides should be tank mixed or rotated on a weekly basis with other currently labeled fungicides with different modes of action (i.e., cyazofamid, mandipropamid, or copper hydroxide). Control is most effective when full coverage of the underside of the leaves in the canopy is achieved. Protectant fungicides such as copper alone may not provide control once the pathogen has infected the plant and begins sporulating on the abaxial surface of infected leaves. Fungicides that provide low to moderate levels of control will result in a product that is not acceptable in the marketplace. Cost of control and the level of disease severity in the field are also considerations that should be determined before any fungicide applications are made. Therefore, growers need to determine the best course of action when growing basil. Because there are no current sweet basil varieties with resistance to BDM and some organic fungicides, such as the ones evaluated in this study, may not provide an adequate level of control, organic basil growers should consider planting alternatives such as Lemon or Spice-type basil species which show resistance or tolerance to P. belbahrii (62).

Additionally, all conventional and organic basil growers should adopt an integrated pest management strategy. Basil growers should know the symptoms of downy mildew, be able to accurately and rapidly identify the disease, follow regional and local reports for outbreaks, and monitor their plantings on a daily basis for presence of the pathogen. There are a number of cultural practices that all basil growers should also consider to help reduce the chances for potential infection and dispersal (e.g., dissemination) of the inoculum. These include purchasing pathogen-free seed, examining transplants for signs of disease, planting less susceptible species or varieties (62), maintaining healthy plants, planting in welldrained soil, maintaining sanitation by controlling weeds and destroying contaminated crops, minimizing leaf wetness and humidity in the plant canopy, harvesting plants before risk of disease is present, increasing plant spacing, planting in an open field in full sunlight exposed to prevailing winds, and reducing or eliminating overhead irrigation. Although untested, the cucurbit downy mildew forecasting website (http://cdm.ipmpipe.org/) is a resource that growers can use to aid in predicting when environmental conditions may be favorable for BDM downy mildew. Thoughts are that the BDM pathogen may disseminate and cause infection in similar conditions as the Cucurbit downy mildew pathogen. Cornell University has also developed a BDM monitoring program that has been in use since 2009 (http://vegetablemdonline.ppath.cornell. edu).

The epidemiology of $P$. belbahrii is still unknown. However, it is believed that the pathogen has spread globally in recent years via the shipment of infested seed and locally or regionally through weather patterns. Because $P$. belbahrii can survive on infested seed, it is most likely the cause of the pathogen being disseminated around the world in a relatively short period of time (http:// vegetablemdonline.ppath.cornell.edu/NewsArticles/BasilDowny.ht $\mathrm{ml}$ ). Although none are currently available, fungicide seed treatments or at-seeding fungicide applications may also aid in controlling disease (10). Other potential methods of seed treatments, such as with hot water or dry heat, need to be examined in order to help prevent the potential wide-scale distribution of the pathogen in seed. Molecular techniques such as the real-time polymerase chain reaction have been developed for detection of BDM from infected tissues and seed which will aid in pathogen detection at the industry and research level (5).

\section{Acknowledgments}

Funding for this project was provided, in part, by the United States Department of Agriculture Specialty Crops Research Initiative project award number 2011-51181-30646 to Rutgers University (in concert with Cornell University, University of Florida, and University of Massachusetts) "Strategies for Improving the U.S. Responses to Fusarium, Downy Mildew and Chilling Injury in Production of Sweet Basil (Ocimum basilicum L.)". Partial funding was also provided by the New Use Agriculture and Natural Plant Products Program and the Rutgers Agricultural Experiment Station and the Rutgers University IR-4 Program. We thank Johnny's Selected Seeds for providing the basil seed used in this study.

\section{Literature Cited}

1. Allen, J. E., and Patrie, A. 2012. Evaluation of organic control products for basil downy mildew, 2011. Plant Dis. Manage. Rep. 6:V073. Online publication. doi:10.1094/PDMR06

2. Allen, J. E., and Saska, M. 2013. Basil downy mildew control using organic fungicides and nitrogen fertilization rates, 2012. Plant Dis. Manage. Rep. 7:V045. Online publication. doi:10.1094/PDMR07

3. Babadoost, M., and DeYoung, A. 2012. Efficacy of selected fungicides for control of downy mildew of basil in Illinois, 2011. Plant Dis. Manage. Rep. 6:V131. Online publication. doi:10.1094/PDMR06

4. Babadoost, M., and DeYoung, A. 2013. Efficacy of selected fungicides for control of downy mildew of basil in Illinois, 2012. Plant Dis. Manage. Rep. 7:V140. Online publication. doi:10.1094/PDMR07

5. Belbahri, L., Calmin, G., Pawlowski, J., and Lefort, F. 2005. Phylogenetic analysis and Real Time PCR detection of a presumably undescribed Peronospora species on sweet basil and sage. Mycol. Res. 109:1276-1287.

6. Chen, C. H., Huang, J. H., and Hsieh, T. F. 2010. First report of Peronospora belbahrii causing downy mildew on basil in Taiwan. Plant Pathol. Bull. 19:177-180.

7. Coosemans, J. 2004. First report of Peronospora lamii, downy mildew on basil (Ocimum basilicum) in Belgium. Parasitica 60:27.

8. Dhar, A. K. 2002. Sweet basil Ocimum basilicum-A review. J. Med. Arom. Plant Sci. 24:738-755.

9. Garibaldi, A., Minuto, A., and Gullino, M. L. 2005. First report of downy mildew caused by Peronospora sp. on basil (Ocimum basilicum) in France. Plant Dis. 89:683.

10. Garibaldi, A., Minuto, A., Minuto, G., and Gullino, M. L. 2004. First report of downy mildew on basil (Ocimum basilicum) in Italy. Plant Dis. 88:312.

11. Gilardi, G., Demarchi, S., Garibaldi, A., and Gullino, M. L. 2012. Management of downy mildew of sweet basil (Ocimum basilicum) caused by Peronospora belbahrii by means of resistance inducers, fungicides, biocontrol agents and natural products. Phytoparasitica 41:59-72.

12. Gullino, M. L., Gilardi, G., and Garibaldi, A. 2009. Chemical control of downy mildew on lettuce and basil under greenhouse. Commun. Agric. Appl. Biol. Sci. 74:933-940.

13. Hansford, C. G. 1933. Annual report of the mycologist. Rev. Appl. Mycol. 12:421-422.

14. Hansford, C. G. 1938. Annual report of the mycologist. Rev. Appl. Mycol. 17:345-346.

15. Heller W., and Baroffio, C. 2003. Le mildiou (Peronospora lamii) du basilic progresse! Gemüsebau/Maraîcher 8:12-13.

16. Khateri, H., Calmin, G., Moarrefzadeh, N., Belbahri, L. and Lefort, F. 2007. First report of downy mildew caused by Peronospora sp. on basil in northern Iran. J. Plant Pathol. 89(Suppl.):S70.

17. Lefort F, Gigon, V., and Amos, B. 2003. Le mildiou s'étend. Déja détecté dans des nombreux pays européens, Peronospora lamii, responsible du mildiou de basilica, a été observe en Suisse dans la region lémanique. Réussir Fruits Légumes 223:66.

18. McGrath, M., Wyenandt, A., and Simon, J. Downy mildew wars. 2010. Am Veg. Grow. 2:10.

19. McGrath, M. T., and Hunsberger, L. K. 2011. Evaluation of biopesticides for managing downy mildew in basil, 2010. Plant Dis. Manage. Rep. 5:V098. Online publication. doi:10.1094/PDMR05 
20. McGrath, M. T., and Hunsberger, L. K. 2012. Evaluation of biopesticides for managing downy mildew in basil, 2011. Plant Dis. Manage. Rep. 6:V099. Online publication. doi:10.1094/PDMR06

21. McGrath, M. T., and LaMarsh, K. A. 2013. Evaluation of fungicides for managing downy mildew in basil, 2012. Plant Dis. Manage. Rep. 7:V015. Online publication. doi:10.1094/PDMR07

22. McGrath, M. T., Wyenandt, C. A., Raid, R. N., Babadoost, M., and Wick, R. L. 2010. Occurrence of basil downy mildew in the eastern U.S. in 2009. (Abstr.) Phytopathology 100:S196.

23. McLeod, A., Coertze, S., and Mostert, L. 2006. First report of a Peronospora species on sweet basil in South Africa. Plant Dis. 90:1115.

24. Mersha, Z., and Zhang, S. 2012. Response of basil cultivars to Peronospora belbahrii after foliar treatment with acibenzolar-S-methyl in the greenhouse. Plant Dis. Manage. Rep. 6:V153. Online publication. doi:10.1094/PDMR06

25. Mersha, Z., Zhang, S., and Fu, Y. 2012. Efficacy of 3-aminobutanoic acid with and without fungicide combination for control of downy mildew in field grown basil, spring, 2011. Plant Dis. Manage. Rep. 6:V029. Online publication. doi:10.1094/PDMR06

26. Mersha, Z., Zhang, S., and Fu, Y. 2012. Effect of rate and application pattern of Prophyt and Quadris tank mix for control of downy mildew in field grown basil, spring 2011. Plant Dis. Manage. Rep. 6:V087. Online publication. doi:10.1094/PDMR06

27. Mersha, Z., Zhang, S., and Fu, Y. 2012. Efficacy of acibenzolar-S-methyl with and without fungicide combination for control of downy mildew in field grown basil, spring 2011. Plant Dis. Manage. Rep. 6:V088. Online publication. doi:10.1094/PDMR06

28. Mersha, Z., Zhang, S., Fu, Y., Mo, X., Raid, R.N., and Hau, B. 2012. Efficacy of acibenzolar-S-methyl and $\beta$-aminobutyric acid for control of downy mildew in greenhouse grown basil and peroxidase activity in response to treatment with these compounds. J. Phytopathol. 161:154-164.

29. Mersha, Z., Zhang, S., and Mo, X. 2011. Evaluation of biologicals and biorationals for control of basil downy mildew under greenhouse conditions, 2010. Plant Dis. Manage. Rep. 6:V059. Online publication. doi:10.1094/PDMR06

30. Mersha, Z., Zhang, S., and Mo, X. 2011. Evaluation of application timing of biological and biofungicides for control of downy mildew on basil, 2010. Plant Dis. Manage. Rep. 6:V060. Online publication. doi:10.1094/PDMR06

31. Mersha, Z., Zhang, S., and Raid, R. N. 2012. Evaluation of systemic acquired resistance inducers for control of downy mildew on basil. Crop Prot. 40:83-90.

32. Nagy, G., and Horváth, A. 2011. Occurrence of downy mildew caused by Peronospora belbahrii on sweet basil in Hungary. Plant Dis. 95:1034.

33. Patel, J. S., Costa de Novaes, M. I., Barbier, M., and Zhang, S. 2013. Evaluation of biopesticides for managing downy mildew of basil, 2013. Plant Dis. Manage. Rep. 7:V147. Online publication. doi:10.1094/PDMR07

34. Patel, J. S., Zhang, S., and Mersha, Z. 2013, August 10-14. Effect of plant age on downy mildew of basil. Poster session 562-P. APS MSA Joint Meeting, Austin, TX.

35. Putievsky, E., and Galambosi, B. 1999. Production systems of sweet basil. Pages 39-65 in: Basil: The Genus Ocimum. R. Hiltunen and Y. Holm, eds. Harwood Academic Publishers, Amsterdam.

36. Raid, R. N. 2008. Evaluation of fungicides for control of downy mildew on basil, Fall 2007. Plant Dis. Manage. Rep. 2:V066. Online publication. doi:10.1094/PDMR02

37. Raid, R. N. 2008. A comparison of Prophyt, Previcur, and Revus for control of downy mildew on basil, Fall 2007. Plant Dis. Manage. Rep. 2:V067. Online publication. doi:10.1094/PDMR02

38. Raid, R. N. 2008. A comparison of select biofungicides and conventional fungicides for control of downy mildew on basil, Fall 2007. Plant Dis. Manage. Rep. 2:V068. Online publication. doi:10.1094/PDMR02

39. Raid, R. N. 2008. A comparison of Rescue, Amistar, and Forum for control of downy mildew on basil, Fall 2007. Plant Dis. Manage. Rep. 2:V069. Online publication. doi:10.1094/PDMR02

40. Raid, R. N. 2008. Evaluation of Prophyt, alone and in combination, for post-infection control of downy mildew on basil, Fall 2007. Plant Dis. Manage. Rep. 2:V070. Online publication. doi:10.1094/PDMR02

41. Raid, R. N. 2008. Evaluation of fungicides for control of downy mildew on basil, Winter 2007. Plant Dis. Manage. Rep. 3:V160. Online publication. doi:10.1094/PDMR03

42. Raid, R. N. 2008. Fungicidal efficacy for control of downy mildew on basil, Winter 2007. Plant Dis. Manage. Rep. 3:V161. Online publication. doi:10.1094/PDMR03

43. Raid, R. N. 2008. Evaluation of fungicides, with and without a phosphonic, for control of downy mildew on basil, Winter 2007. Plant Dis. Manage. Rep. 3:V162. Online publication. doi:10.1094/PDMR0.

44. Raid, R. N. 2008. Efficacy of four fungicides, alone and in tank mixtures with a phosphonic, for control of downy mildew on basil, Winter 2007. Plant Dis. Manage. Rep. 3:V163. Online publication. doi:10.1094/PDMR03

45. Raid, R. N. 2011. Evaluation of BAS-651 for control of basil downy mildew, Spring 2010. Plant Dis. Manage. Rep. 5:V046. Online publication. doi:10.1094/PDMR05

46. Raid, R. N. 2011. Evaluation of Regalia, alone and in tank-mixture, for control of basil downy mildew, Fall 2010. Plant Dis. Manage. Rep. 5:V155. Online publication. doi:10.1094/PDMR05

47. Raid, R. N., Raid, S., and Hartman, D. 2013. Evaluation of fungicides for control of downy mildew on sweet basil, Fall 2012. Plant Dis. Manage. Rep. 7:V146. Online publication. doi:10.1094/PDMR07

48. Raid, R. N., Roberts, P. D., Harmon, P. F., Palmateer, A. J., and Jordan, S A. 2010. Basil downy mildew in Florida: A disease of new importance. Phytopathology. APS Caribbean Div. 2009 Caribbean Div. Meet. Abstr. 100:S175.

49. Raid, R. N., and Sui, D. 2011. Evaluation of fungicides for control of downy mildew on sweet basil, Spring 2010. Plant Dis. Manage. Rep. 5:V045. Online publication. doi:10.1094/PDMR05

50. Raid, R. N., and Sui, D. 2011. Evaluation of fungicides for control of basil downy mildew, Fall 2010. Plant Dis. Manage. Rep. 5:V157. Online publication. doi:10.1094/PDMR05

51. Raid, R. N., Sui, D., and Zhang, S. 2011. Comparison of five fungicides of dissimilar modes of action for control of downy mildew on sweet basil, Spring 2010. Plant Dis. Manage. Rep. 5:V047. Online publication. doi:10.1094/PDMR05

52. Raid, R. N., Sui, D., and Zhang, S. 2011. Evaluation of registered fungicides for control of downy mildew on sweet basil, Spring 2010. Plant Dis Manage. Rep. 5:V048. Online publication. doi:10.1094/PDMR05

53. Roberts, P. D., Raid, R. N., Harmon, P. F., Jordan, S. A., and Palmateer, A J. 2009. First report of downy mildew caused by a Peronospora sp. on basil in Florida and the United States. Plant Dis. 93:199.

54. Ronco, L., Rollán, C., Choi, Y. J., and Shin, H. D. 2009. Downy mildew of sweet basil (Ocimum basilicum) caused by Peronospora sp. in Argentina. Plant Pathol. 58:395.

55. Saude, C., Westerveld, S., and Filotas, M. 2013. First report of downy mildew caused by Peronospora belbahrii on basil (Ocimum spp.) in Ontario. Plant Dis. 97:1248.

56. Simon, J. E., Morales, M. R., Phippen, W. B., Vieira, R. F., and Hao, Z. 1999. Basil: A source of aroma compounds and a popular culinary and ornamental herb. Pages 499-505 in: Perspectives on New Crops and New Uses. J. Janick, ed. ASHS Press, Alexandria, VA

57. Simon, J. E., Quinn, J., and Murray, R. G. 1990. Basil: A source of essential oils. Pages 484-489 in: Advances in New Crops. J. Janick and J. E. Simon, eds. Timber Press, Portland OR.

58. Thines, M., Telle, S., Ploch, S., and Runge, F. 2009. Identity of the downy mildew pathogens of basil, coleus, and sage with implications for quarantine measures. Mycol. Res. 13:532-540.

59. Vieira, R. F., Goldsbrough, P., and Simon, J. E. 2003. Genetic diversity of basil (Ocimum spp.) based on RAPD markers. J. Am. Soc. Hortic. Sci. 128:94-99.

60. Voglmayr, H., and Piątek, M. 2008. Peronospora causing downy mildew disease of sweet basil newly reported in Cameroon. Plant Pathol. 58:805.

61. Wick, R. L., and Brazee, N. J. 2009. First report of downy mildew caused by a Peronospora species on sweet basil (Ocimum basilicum) in Massachusetts. Plant Dis. 93:318.

62. Wyenandt, C. A., Simon, J. E., McGrath, M. T., and Ward, D. L. 2010. Susceptibility of basil cultivars and breeding lines to downy mildew (Peronospora belbahrii). HortScience 45:1416-1419. 